\title{
INFLUENCE OF FERTILIZER TREATMENT ON THE CHEMICAL COMPOSITION OF SOME CALENDULA OFFICINALIS VARIETIES CULTIVATED IN ROMANIA
}

\author{
ILIOARA ONIGA $^{1}$, ANCA TOIU ${ }^{1 *}$, DANIELA HANGANU ${ }^{1}$, LAURIAN VLASE ${ }^{1}$, MARCEL \\ DUDA $^{2}$, DANIELA BENEDEC ${ }^{1}$ \\ I "Iuliu Haţieganu” University of Medicine and Pharmacy, Faculty of Pharmacy, 12 Ion Creangă Street, 400010, Cluj- \\ Napoca, Romania \\ ${ }^{2}$ University of Agricultural Sciences and Veterinary Medicine Cluj-Napoca, Faculty of Agriculture, Department of \\ Phytotechnology, 3-5 Mănăștur Alley, 400372, Cluj-Napoca, Romania
}

*corresponding author: ancamaria_toiu@yahoo.com

\begin{abstract}
In order to select a good genetic material for cultivation, the influence of fertilizer on the biosynthesis of active principles from the inflorescences of six Calendula officinalis L. (marigold) varieties was investigated. The marigold flowers were cultivated and harvested from Romania, Cluj County. The qualitative and quantitative analyses were performed by spectrophotometric methods and HPLC. The concentrations of flavonoids ( $0.43-0.66 \%$, expressed in rutin), phenylpropane derivatives $(0.21-1.25 \%$, expressed in caffeic acid) and carotenoids $(0.40-0.75 \%$, expressed in beta-carotene $)$ were determined. Although the 'Agrosel 696' and 'Starsem 922' varieties were the richest in flavonoids and phenylpropane derivatives, other varieties, as 'Cluj 2' and 'Novi Sad' may be preferred for cultivation as natural sources of carotenoids. The use of fertilizer stimulated, in small degree, the biosynthesis of flavonoids, but it decreased the quantities of carotenoids and phenylpropane derivatives. All samples were in accordance with the requirements of the European Pharmacopoeia (min $0.4 \%$ flavonoids).
\end{abstract}

\section{Rezumat}

În vederea selecţionării unui material genetic avantajos pentru introducerea în cultură, s-a urmărit influența utilizării de fertilizant asupra biosintezei de principii active în inflorescențe de Calendula officinalis L. (gălbenele), recoltate de la 6 varietăţi cultivate în judeţul Cluj. Analizele calitative şi cantitative s-au efectuat prin metode spectrofotometrice și HPLC. S-au determinat concentrațiile de flavonoide $(0,43-0,66 \%$, exprimate în rutozidă), derivaţi fenilpropanici $(0,21-1,25 \%$, exprimaţi în acid cafeic) și carotenoide (0,40 - 0,75\%, exprimate în beta-caroten). S-au remarcat varietățile 'Agrosel 696' și 'Starsem 922', mai bogate în flavonoide și derivați fenilpropanici și varietățile 'Cluj 2' și 'Novi Sad' cu concentraţii ridicate de carotenoide. Utilizarea de fertilizant a stimulat în mică măsură biosinteza de flavonoide, dar a scăzut cantitățile de carotenoide și derivați fenilpropanici. Toate probele au fost conforme cu prevederile Farmacopeei Europene (min. 0,4\% flavonoide).

Keywords: Calendula officinalis, fertilizer, flavonoids, carotenoids

\section{Introduction}

Calendula officinalis L. (Asteraceae), the marigold, is a perennial cultivated plant used worldwide in pharmaceutical and cosmetic products. The flowers contain active principles like polyphenols (flavonoids, caffeic acid derivatives, tannins), terpenes (saponins, carotenoids), essential oil, polysaccharides. The extracts are used for their anti-inflammatory, antimicrobial, emollient, trophic, protective and healing properties, especially in topical application, to treat minor wounds, skin disorders, superficial burns or as analgesic in mouth or pharyngeal diseases $[3,6,7,9]$.

The aim of this study was to evaluate the content in some active principles (flavonoids, phenylpropane derivatives, carotenoids) from the inflorescences of 6 Calendula officinalis varieties cultivated in Cluj County,
Romania, in condition of using different quantities of natural fertilizer (farmyard manure) to increase the soil fertility.

\section{Materials and Methods}

The inflorescences of Calendula officinalis were harvested from 6 varieties, cultivated in the experimental fields of UASVM Cluj-Napoca (Jucu, Cluj County, Romania): 'Petrana' variety (sample 1), 'Cluj 2' variety (sample 2), 'Novi Sad' variety (sample 3), 'Agrosel 696' variety (sample 4), 'Starsem 922' variety (sample 5), 'Belleza del Pacifico' variety (sample 6) [4]. The voucher specimens of the studied plants were stored in the Herbarium of the Pharmacognosy Department, Faculty of Pharmacy, Cluj-Napoca, Romania (Voucher no. 40 - 46). The plants were 
FARMACIA, 2018, Vol. 66, 6

cultivated in different agrotechnical conditions: without fertilizer (F0) and respectively with 20 t/ha (F20), and $40 \mathrm{t} / \mathrm{ha}$ (F40) fertilizer.

Total flavonoids, phenolic acids (phenylpropane derivatives) and carotenoids contents were determined by spectrophotometric methods, using an UV-VIS JASCO V-530 spectrophotometer $[11,13,16,19]$. The spectrophotometric aluminium chloride method was used for the determination of flavonoids. The absorbance was measured at $430 \mathrm{~nm}$. The total flavonoids content values were determined using an equation obtained from calibration curve of the rutin graph $\left(\mathrm{R}^{2}=0.9996\right)$ [18]. The total phenolic acids content in the plant material was determined using the spectrophotometric method with Arnow's reagent [19]. The absorbance was determined at 500 $\mathrm{nm}$. The percentage of phenolic acids, expressed as caffeic acid equivalent on dry weight, was calculated using an equation obtained from calibration curve of caffeic acid graph $\left(\mathrm{R}^{2}=0.9941\right)$. Quantitative determination of carotenoids [11] was carried out using a spectrophotometric method, the absorbance was determined at $450 \mathrm{~nm}$. The carotenoid contents were calculated using the formula: mg carotenoids/ $100 \mathrm{~g}$ sample $=(\mathrm{A} \cdot \mathrm{V} \cdot 1000) /\left(\mathrm{A}_{1 \mathrm{~cm}}{ }^{1 \%} \cdot \mathrm{M}\right)$, where: $\mathrm{A}=$ absorbance of the solution at $450 \mathrm{~nm} ; \mathrm{V}=$ the volume of the solution $(=50 \mathrm{~mL}) ; \mathrm{A}_{1 \mathrm{~cm}}{ }^{1 \%}=$ the specific absorbance of $\beta$-carotene $(=2500) ; \mathrm{M}=$ the mass of the test sample $(\mathrm{g})$.

The identification and quantification of phenolic compounds were made by HPLC $[1,2,5,8,10]$. The analyses were carried out using an Agilent 1100 HPLC Series system (Agilent USA), binary pump. The separation was done using a Zorbax SBC18 reverse-phase column $(100 \times 3.0 \mathrm{~mm}$ i.d., $3.5 \mu \mathrm{m}$ particles), using the previous described conditions $[12,14,15,17]$. Quantitative determinations were performed using an external standard method.

Standards: 18 polyphenolic compounds: caftaric, gentisic, caffeic, chlorogenic, $p$-coumaric, ferulic, sinapic acids, hyperoside, isoquercitrin, rutin, myricetin, fisetin, quercitrin, quercetin, patuletin, luteolin, kaempferol, apigenin.
HPLC analysis. Samples preparation: dried natural products were extracted with methanol (1:10) after degreasing with chloroform in the Soxhlet apparatus. In order to obtain more accurate data on the studied compounds, each sample was analysed before and after acid hydrolysis. $2 \mathrm{~mL}$ extractive solution was treated with $2 \mathrm{~mL} 2 \mathrm{M}$ hydrochloric acid and $0.2 \mathrm{~mL}$ ascorbic acid solution $100 \mathrm{mg} / \mathrm{mL}$, and the mixtures were heated at $80^{\circ} \mathrm{C}$ on a water bath for $30 \mathrm{~min}$, ultrasonicated for $15 \mathrm{~min}$, and heated for another 30 $\min$ at $80^{\circ} \mathrm{C}$. Quantification was performed on the basis of linear calibration plots of peak area against concentration. All compounds were identified by both standard addition and comparison of their retention times and MS spectra with those of standards in the same chromatographic conditions.

Statistical analysis. The samples were analysed in triplicate; the average and the relative SD were calculated using the Excel software package.

\section{Results and Discussion}

The quantitative determination of carotenoids and phenylpropane derivatives showed a decrease in active compounds concentration when a higher quantity of fertilizer was used. For the flavonoid content, increasing the amount of fertilizer determined a slightly increase in the concentration levels. The richest variety in carotenoids was 'Cluj 2' (749.5 mg/100 g vegetal product), with the more intensive orange colour of the inflorescences. High flavonoid contents were found in 'Agrosel 696', 'Starsem 922' and 'Belleza del Pacifico' varieties (more than $0.58 \%$ ). The variety 'Starsem 922' was the richest in phenylpropane derivatives (1.25\%). Although for 'Belleza del Pacifico' variety the highest production of inflorescences was observed, the carotenoids $(549.5 \mathrm{mg} / 100 \mathrm{~g}$ vegetal product) and phenylpropane derivatives levels $(0.46 \%)$ were lower, and only the flavonoids $(0.58-0.67 \%)$ were determined in high concentrations (Table I). The flavonoid contents were in accordance with European Pharmacopoeia in all samples (min. 0.4\% flavonoids) [19].

Table I

The concentrations of carotenoids, flavonoids and phenylpropane derivatives in C. officinalis varieties

\begin{tabular}{|c|c|c|c|c|c|c|c|c|c|}
\hline \multirow{2}{*}{$\begin{array}{l}\text { Sample } \\
\text { C. officinalis/ } \\
\text { variety }\end{array}$} & \multicolumn{3}{|c|}{$\begin{array}{c}\text { Carotenoids } \\
\text { ( } \beta \text {-carotene }-\mathrm{mg} / 100 \mathrm{~g} \text { vegetal product) }\end{array}$} & \multicolumn{3}{|c|}{$\begin{array}{c}\text { Flavonoids } \\
\text { (rutin- } \mathrm{mg} / 100 \text { g vegetal product) }\end{array}$} & \multicolumn{3}{|c|}{$\begin{array}{c}\text { Phenylpropane derivatives (caffeic acid - } \\
\text { mg/100 g vegetal product) }\end{array}$} \\
\hline & $F_{0}$ & $F_{20}$ & $F_{40}$ & $\mathbf{F}_{\mathbf{0}}$ & $F_{20}$ & $\mathrm{~F}_{40}$ & $F_{0}$ & $\mathrm{~F}_{20}$ & $\mathbf{F}_{40}$ \\
\hline $\begin{array}{c}\mathbf{1} \\
\text { Petrana } \\
\end{array}$ & $614.9 \pm 0.01$ & $487.3 \pm 0.02$ & $406.2 \pm 0.01$ & $479.95 \pm 0.05$ & $534.74 \pm 0.04$ & $604.76 \pm 0.02$ & $714.14 \pm 0.03$ & $214.89 \pm 0.04$ & $263.69 \pm 0.02$ \\
\hline $\begin{array}{c}\mathbf{2} \\
\text { Cluj } 2 \\
\end{array}$ & $749.5 \pm 0.04$ & $640.1 \pm 0.03$ & $485.6 \pm 0.06$ & $551.64 \pm 0.01$ & $553.95 \pm 0.05$ & $588.51 \pm 0.03$ & $593.14 \pm 0.02$ & $439.61 \pm 0.03$ & $288.46 \pm 0.03$ \\
\hline $\begin{array}{c}\mathbf{3} \\
\text { Novi Sad }\end{array}$ & $715.0 \pm 0.03$ & $574.9 \pm 0.02$ & $434.9 \pm 0.11$ & $660.12 \pm 0.03$ & $430.04 \pm 0.02$ & $604.31 \pm 0.03$ & $809.72 \pm 0.04$ & $338.59 \pm 0.01$ & $286.74 \pm 0.02$ \\
\hline $\begin{array}{c}\mathbf{4} \\
\text { Agrosel } 696 \\
\end{array}$ & $490.6 \pm 0.01$ & $438.9 \pm 0.01$ & $408.9 \pm 0.05$ & $580.21 \pm 0.05$ & $514.05 \pm 0.05$ & $548.38 \pm 0.02$ & $976.47 \pm 0.05$ & $275.22 \pm 0.02$ & $399.94 \pm 0.04$ \\
\hline $\begin{array}{c}\mathbf{5} \\
\text { Starsem } 922\end{array}$ & $676.3 \pm 0.05$ & $594.5 \pm 0.04$ & $434.2 \pm 0.04$ & $583.96 \pm 0.06$ & $555.88 \pm 0.06$ & $581.57 \pm 0.04$ & $1253.39 \pm 0.02$ & $455.87 \pm 0.04$ & $365.71 \pm 0.01$ \\
\hline $\begin{array}{c}\mathbf{6} \\
\text { Belleza del Pacifico }\end{array}$ & $549.5 \pm 0.02$ & $537.5 \pm 0.03$ & $511.7 \pm 0.04$ & $585.44 \pm 0.02$ & $531.67 \pm 0.02$ & $675.59 \pm 0.05$ & $459.25 \pm 0.05$ & $210.82 \pm 0.03$ & $268.44 \pm 0.02$ \\
\hline
\end{tabular}


FARMACIA, 2018, Vol. 66, 6

In order to analyse the influence of fertilizer on the phenolic compounds from $C$. officinalis flowers ('Belleza del Pacifico' variety), a HPLC analysis was performed. No significant differences were observed when comparing the results obtained for the determination of composition from the flowers when the fertilizer treatment was used, the highest levels being found in the samples cultivated without fertilizer. The major compounds were the flavonoid glycosides isoquercitrin (3-O-glucoside of quercetin) and rutin (quercetin-3-O-rutinoside). After hydrolysis some aglycons were identified (quercetin, kaempferol, luteolin, apigenin). The identified compounds are presented in Table II.

Table II

Phenolic compounds identified by HPLC performed on sample 6

\begin{tabular}{|c|c|c|c|c|c|c|c|}
\hline \multirow[t]{2}{*}{ Identified compounds } & \multirow[t]{2}{*}{$\begin{array}{l}\mathrm{RT} \pm \mathrm{SD} \\
(\mathrm{min})\end{array}$} & \multicolumn{2}{|c|}{$\begin{array}{l}\text { C. officinalis } \\
\mathrm{F} 0(\mu \mathrm{g} / \mathrm{mL})\end{array}$} & \multicolumn{2}{|c|}{$\begin{array}{l}\text { C. officinalis } \\
\text { F20 }(\mu \mathrm{g} / \mathrm{mL})\end{array}$} & \multicolumn{2}{|c|}{$\begin{array}{l}\text { C. officinalis } \\
\mathrm{F} 40(\mu \mathrm{g} / \mathrm{mL})\end{array}$} \\
\hline & & $\mathrm{NH}$ & $\mathrm{H}$ & $\mathrm{NH}$ & $\mathrm{H}$ & $\mathrm{NH}$ & $\mathrm{H}$ \\
\hline Gentisic acid & $3.70 \pm 0.07$ & - & $\mathrm{x}$ & & $\mathrm{x}$ & - & $\mathrm{x}$ \\
\hline Caffeic acid & $5.90 \pm 0.04$ & $\mathrm{x}$ & $\mathrm{x}$ & $\mathrm{x}$ & $\mathrm{x}$ & $\mathrm{x}$ & $\mathrm{x}$ \\
\hline Chlorogenic acid & $6.62 \pm 0.05$ & $\mathrm{x}$ & $\mathrm{x}$ & $\mathrm{x}$ & & $\mathrm{x}$ & $\mathrm{x}$ \\
\hline p-Coumaric acid & $9.20 \pm 0.08$ & - & $0.10 \pm 0.03$ & - & $\mathrm{x}$ & - & $0.25 \pm 0.03$ \\
\hline Ferulic acid & $12.40 \pm 0.10$ & - & $0.35 \pm 0.14$ & - & $\mathrm{X}$ & $\mathrm{X}$ & $\mathrm{X}$ \\
\hline Isoquercitrin & $19.90 \pm 0.10$ & $7.41 \pm 1.08$ & - & $5.80 \pm 0.90$ & & $6.10 \pm 0.89$ & - \\
\hline Rutin & $20.40 \pm 0.15$ & $3.67 \pm 0.32$ & - & $3.10 \pm 0.69$ & & $3.49 \pm 0.50$ & - \\
\hline Quercetin & $26.80 \pm 0.15$ & - & $4.71 \pm 0.58$ & - & $4.35 \pm 0.54$ & $2.17 \pm 0.42$ & $4.21 \pm 0.38$ \\
\hline Luteolin & $29.20 \pm 0.19$ & - & - & - & $0.16 \pm 0.03$ & - & - \\
\hline Kaempferol & $31.78 \pm 0.17$ & - & $0.30 \pm 0.09$ & - & $0.37 \pm 0.12$ & $\mathrm{x}$ & $0.40 \pm 0.19$ \\
\hline Apigenin & $33.20 \pm 0.15$ & - & - & & & - & $0.14 \pm 0.01$ \\
\hline
\end{tabular}

$\mathrm{NH}=$ non-hydrolysed sample; $\mathrm{H}=$ hydrolysed sample; $-=$ not found; $\mathrm{x}=$ qualitatively identified by MS

The concentrations of the active principles varied in the 6 investigated varieties of $C$. officinalis: for the flavonoids content stood out 'Agrosel 696', 'Starsem 922' and 'Belleza del Pacifico' varieties, for the carotenoids content 'Cluj 2' and 'Novi Sad' varieties, and for the phenylpropane derivatives content, the 'Starsem 922' and 'Agrosel 696' varieties. The use of fertilizer in different proportions was an advantage in order to obtain a higher production of flowers, but this was not in relationship with the levels of active principles, except the flavonoids.

\section{Conclusions}

The contents of active compounds in the inflorescences of 6 varieties of $C$. officinalis were investigated, in order to evaluate the quality of natural product and the influence of the fertilizer used in cultivation. The 'Agrosel 696' and 'Starsem 922' varieties may be considered suitable for the cultivation as natural sources of flavonoids and phenylpropane derivatives, while 'Cluj 2' and 'Novi Sad' varieties are important sources of carotenoids. Although there appears to be no evident advantage between the use of fertilizer and the carotenoids and phenylpropane derivatives contents, a slightly increase in flavonoids level was observed.

\section{Acknowledgement}

We acknowledge the financial support from the Romanian Executive Agency for Higher Education, Research, Development and Innovation Funding, research grant PN-II-RU-TE-2014-4-1247.

\section{References}

1. Benedec D, Hanganu D, Oniga I, Filip L, Bischin C, Silaghi-Dumitrescu R, Tiperciuc B, Vlase L, Achillea schurii Flowers: Chemical, Antioxidant, and Antimicrobial Investigations. Molecules, 2016; 21(8): 1050.

2. Benedec D, Vlase L, Oniga I, Mot AC, SilaghiDumitrescu R, Hanganu D, Tiperciuc B, Crişan G, LC-MS analysis and antioxidant activity of phenolic compounds from two indigenous species of Mentha. Note I. Farmacia, 2013; 61(2): 261-267.

3. Bruneton J, Pharmacognosie, Phytochimie, Plantes medicinales, $2^{\text {nd }}$ edition, Paris, Ed. Technique et Documentation, 1999; 705-706.

4. Duda MM, Vârban DI, Muntean S, Banga D, A review regarding yielding capacity and qualitative parameters of marigold (Calendula officinalis L.) cultivars in a collection field, Cluj Napoca, Romania. Proceedings of the $5^{\text {th }}$ Conference on Medicinal and Aromatic Plants of Southeast European Countries, Mendel University of Agriculture and Forestry Brno, 2008; 94.

5. Fodorea CS, Vlase L, Leucuta SE, Tamas M, Phytochemical study on some polyphenols of Geranium pyrenaicum. Chem Nat Compounds, 2005; 41(4): 400-403.

6. Fonseca YM, Catini CD, Vicentini FT, Nomizo A, Gerlach RF, Fonseca MJ, Protective effect of Calendula officinalis extract against UVB-induced oxidative stress in skin: Evaluation of reduced glutathione levels and matrix metalloproteinase secretion. J Ethnopharmacol., 2010; 127: 596-601.

7. Fronza M, Heinzmannnn B, Hamburger M, Laufer S, Merfort I, Determination of the wound healing effect of Calendula extracts using the scratch assay with 3T3 fibroblasts. J Ethnopharmacol., 2009; 126: 463-467. 
8. Hanganu D, Benedec D, Vlase L, Popica I, Bele C, Raita O, Gheldiu AM, Mihali CV, Țărmure V, Polyphenolic Content And Antioxidant Activity Of Chrysanthemum Parthenium Extract. Farmacia, 2016; 64(4): 498-501.

9. Kurkin VA, Sharova OV, Flavonoids from Calendula officinalis flowers. Chem Nat Compd., 2007; 43: 216-217.

10. Meda RNT, Vlase L, Lamien-Meda A, Lamien CE, Muntean D, Tiperciuc B, Oniga I, Nacoulma OG, Identification and quantification of phenolic compounds from Balanites aegyptiaca (L) Del (Balanitaceae) galls and leaves by HPLC-MS. Nat Prod Res., 2011; 25(2): 93-99.

11. Oniga I, Tămaş M, Toiu A, Fodorea C, Voştinaru O, Popovici EJ, Vădan M, Researches on pigments from ozone-treated apple. Clujul Medical, 2004; 77(4): 789-792. (available in Romanian)

12. Oniga I, Toiu A, Benedec D, Tomuţă I, Vlase L, Phytochemical analysis of Hypericum maculatum in order to obtain standardized extracts. Farmacia, 2016; 64(2): 171-174.

13. Oniga I, Vlase L, Toiu A, Benedec D, Duda M, Evaluation of phenolic acid derivatives and essential oil content in some Melissa officinalis L. varieties. Farmacia, 2010; 58(6): 764-769.

14. Parvu M, Toiu A, Vlase L, Parvu AE. Determination of some polyphenolic compounds from Allium species by HPLC-UV-MS. Nat Prod Res., 2010; 24(14): 1318-1324.

15. Peev CI, Vlase L, Antal DS, Dehelean CA, Szabadai $Z$, Determination of some polyphenolic compounds in buds of Alnus and Corylus species by HPLC. Chem Nat Compounds, 2007; 43(3): 259-262.

16. Raal A, Kirsipuu K, Total flavonoid content in varieties of Calendula officinalis L. originating from different countries and cultivated in Estonia. Nat Prod Res., 2011; 25(6): 658-662.

17. Toiu A, Vlase L, Arsene AL, Vodnar DC, Oniga I, LC/UV/MS Profile of polyphenols, antioxidant and antimicrobial effects of Ajuga genevensis L. extracts. Farmacia, 2016; 64(1): 53-57.

18. $\mathrm{xxx}$ - European Pharmacopoeia, $8^{\text {th }}$ Ed., Council of Europe, Strasbourg, 2014.

19. xxx - Romanian Pharmacopoeia, ed. a X-a, Ed. Medicală, Bucharest, 1993. (available in Romanian) 